\title{
The Active Role Of Fostering The Regional Indonesian National Sports Committee In Badminton
}

\author{
Fitrah Miko \\ Phisycal Education, Post Graduate Program \\ Universitas Negeri Medan \\ Medan, Indonesia \\ fitrahmiko27@gmail.com
}

\author{
Albadi Sinulingga \\ Phisycal Education, Post Graduate Program \\ Universitas Negeri Medan \\ Medan, Indonesia
}

\author{
Suprayitno \\ Phisycal Education, Post Graduate Program \\ Universitas Negeri Medan \\ Medan,Indonesia
}

\begin{abstract}
The research aims to find out the active role of KONI in Central Aceh Regency in the badminton sport in 2016. The study used a survey method with research subjects KONI management, PBSI management, club management, coaches and athletes. The research instrument was in the form of a questionnaire. Data analysis techniques use percentages. The results showed that the category was quite good. The conclusion is that the role of the coach of bulutangis in the Central Aceh District is quite active.
\end{abstract}

\section{Keywords-Active Role Coaching, KONI, Badminton}

\section{INTRODUCTION}

Badminton is a sport that is loved by people all over the world, including in Indonesia. According to [1] "badminton is a game where every player needs a racket". As a substitute for the ball in a tennis game, it is used as a satelkok (shuttlecock) which is hit back and forth over the net at a certain height. Badminton in Indonesia has been known for a long time, so this sport is a sport that is quite popular among the people of Indonesia. As stated by [2] that "badminton has been known in Indonesia since the Dutch colonial era".

However, in the last few years, the performance of badminton in Indonesia has decreased, arguably reaching its lowest point. This is due to the lack of interest of children to play badminton. Besides the unequal socialization of badminton to the younger generation in Indonesia, the development of badminton is decreasing because of the rarity of giving birth to quality athletes seeds such as Indonesia's heyday in the $90 \mathrm{~s}$.

"Then one of KONI's tasks is to foster and coordinate the parent organizations of sports branches, functional sports organizations, and Provincial and KONI Regencies / Cities and carry out management, coaching and development of sports achievements based on their authority"[3].

The Indonesian National Sports Committee (KONI) as the parent of national sports organizations which oversees all sports branch organizations in Indonesia. In article 36 paragraph (4) of the Law of the Republic of Indonesia Number
3 of 2005 concerning the National Sports system, namely KONI has the task of assisting the government in making national policies in the field of management, fostering, and developing national achievement sports [4].

From the results of the writer's observation in the Central Aceh District KONI office, the author's observation that achievement and interest in badminton is very minimal, due to lack of socialization to children and adolescents in Takengon by local KONI administrators. Badminton matches are rarely held at the district or sub-district level, in addition to the lack of infrastructure and supporting facilities for badminton making the development of badminton in Central Aceh seem less visible [5].

Based on the observations of the authors take the assumption to arouse achievements, interests of children and adolescents towards badminton by conducting socialization to areas in Central Aceh by related parties in particular (KONI and PBSI districts) and conducting cooperation between KONI and village officials so that each village has 1 badminton club to foster, besides supporting facilities are also needed so that the interests of children and adolescents in Central Aceh revive badminton.

Based on that the authors are interested in expressing a research model entitled "The Active Role of KONI Development in Central Aceh Regency in the Badminton Sport Branch.

\section{METHODS}

The study was conducted at the Central Aceh District KONI Office in 2016. The population in this study were all KONI daily administrators, amounting to 39 people, PBSI daily management 25 people, PB Casper club management 15 people, 2 coaches, 22 athletes so that the total population is 103 people. While the samples in this study were the Chairperson of the Central Aceh District KONI, secretaries and chairpersons, members of the field in management, PBSI Chairmen in Central Aceh, secretaries and field members, club officials, coaches and athletes with a total of 50 people.

In this study after the author made a questionnaire then tested the validity and reliability, the questionnaire was 
distributed and filled out by respondents who have been determined. Data processing techniques using quantitative descriptive and the results of data analysis from this study were processed to obtain results using the determination of the score (scoring).

\section{RESULTS AND DISCUSSION}

Before the study was conducted, researchers first tested the questionnaire, in the form of a validity and reliability test. The trial was carried out in KONI, Central Aceh District, PBSI Aceh Tengah, PB Casper club, PB Aman Dimot club which was tested on 30 people who had the same criteria as the study sample.

Based on a questionnaire that was declared valid and reliable, 30 questions were obtained and distributed to a research sample of 50 people.

\section{RESULTS}

The study consisted of two indicators, namely activities and results. The activity indicators consist of several sub-indicators, namely taking part, involving athletes, netting athletes and intensive coaching. While the outcome indicators consist of seven sub-indicators namely motivation, trainers, facilities, research results, training programs, agencies and funds. Then the researchers combined the results of the two indicators as follows:

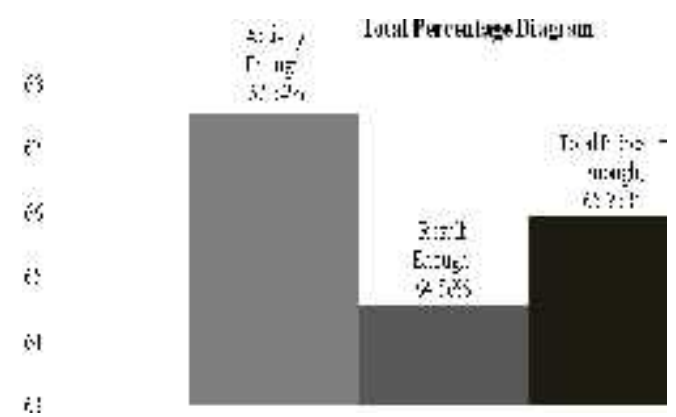

Discussion of Research Results

From the data obtained it was concluded that the overall percentage of data on the activity indicators was $67.54 \%$ with a fairly good category. While the results indicator obtained the overall percentage of data amounted to $64.56 \%$ with the category quite good. Thus the active role of developing KONI Aceh Tengah in badminton is included in the quite good category, with a total percentage of $65.95 \%$.

\section{CONCLUSION}

The active role of KONI in Central Aceh Regency in the badminton sports category is quite good.

\section{REFERENCES}

[1] A. Abdullah. 1985. OlahragaUntuk Pelatih dan Penggemar. Yogyakarta: PT Sastra Hudaya.

[2] Sukintaka. 1979. Permainan dan Metodik. Jakarta: Tarata Bandung.

[3] Komite Olahraga Nasonal Indonesia. 2014. Grand Stategi. Jakarta: PT Gramedia.

[4] S. Arikunto. 2013. Dasar-Dasar Evaluasi Pendidikan. Jakarta: Bumi Aksara.

[5] A Sunarno dan Syaifullah. 2011. Metode Penelitian Keolahragaan. Surakarta : Yusma Pustaka. 